\title{
EFFECT OF USING "AVIZYM 1500 " ENZYME ON PERFORMANCE OF JAPANESE QUAIL FED OPTIMAL AND SUB-OPTIMAL ENERGY LEVELS
}

\author{
M.A.A. Abdel-Mageed and E.M. EL-Kamash
}

Animal Prod. Res. Inst., Agric. Res. Center, Ministry of Agric, Doki, Giza, Egypt.

\begin{abstract}
An on-farm experiment was conducted using 240 one-day old Japanese quail chicks which, individually wing-banded, weighed and randomly distributed into four experimental groups of similar mean body weight of three replicates each and aimed to study the possibility of improving the ME of SBM-based diets fed to Japanese quail (Coturnix coturnix japonica) by dietary addition of a commercial enzyme

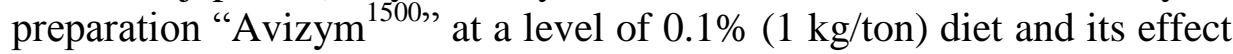
on growth performance, some carcass traits, intestinal viscosity and incidence of pasting vents, volatile fatty acid concentration in cecum, and laying performance. Two experimental starter-grower corn-soybean meal diets (C-SBM) were formulated to be iso-nitrogenous $(24 \% \mathrm{CP})$ and containing two ME levels (2900 and $2750 \mathrm{kcal} \mathrm{ME} / \mathrm{kg}$ diet). Also, two experimental C-SBM layer basal diets were formulated to be isonitrogenous (20\% CP) and containing two ME levels (2900 and 2750 $\mathrm{kcal} \mathrm{ME} / \mathrm{kg}$ diet). Four dietary treatments in both starting-growing and laying periods were compared; two treatments consisted of the two basal diets without "Avizym" ${ }^{1500 "}$ supplementation and two treatments consisted of the two basal diets supplemented with "Avizym" ${ }^{1500 "}$ " at a level of $0.1 \% \quad(1 \mathrm{~kg} / \mathrm{ton})$. Live growth performance, carcass characteristics, intestinal viscosity and incidence of pasting vents, volatile fatty acid concentration in cecum and laying performance were determined. Generally, supplementing Avizym ${ }^{1500}$ to RE-diet gave equal performance to the corresponding Avizym ${ }^{1500}$-free diet (Control). But, supplementing Avizym ${ }^{1500}$ to LE-diet significantly improved performance index (PI) and growth rat (GR), egg production (EP\%), egg number $(\mathrm{EN})$, egg weight $(\mathrm{EW})$, egg mass $(\mathrm{EM})$, feed conversion ratio (FCR), carcass parameters $\%$, liver, heart and edible giblets $\%$. However, it significantly decreased mortality rate (MR\%), abdominal fat $\%$, the viscosity in different parts of intestine, pasting vents $\%$ and Feed intake (FI). Nutritionally, it could be concluded that supplementing

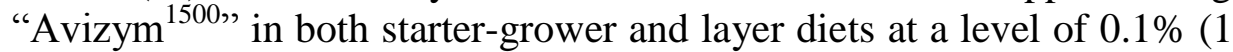
$\mathrm{kg} / \mathrm{ton}$ ) helped in improving quail performance, carcass traits and egg production traits.
\end{abstract}

Fayoum J. Agric. Res. \& Dev., Vol. 30, No.1, January, 2016 
Key words: Performance, growth, slaughter, carcass, intestinal viscosity, pasting vents, volatile fatty acid, egg production and Japanese quail.

\section{INTRODUCTION}

Corn and soybean meal (SBM) are commonly used in poultry diets for their high available energy and protein, respectively. However, corn and SBM contain 9.7 and $21.7 \%$ non-starch polysaccharides (NSP), respectively (Knudsen, 2001). Honig and Rakis (1979) noted that the carbohydrate fraction of SBM is made up almost equally of various oligo- and polysaccharides. Galactosyl oligosaccharides include $\alpha$-galactosides (raffinose, stachyose and verbascose) and $\beta$-galactomannan are present in SBM in relatively high amount. Kennedy et al. (1985) reported that SBM contains $4.00-7.67 \%$ sucrose, $0.67-0.94 \%$ raffinose, $2.96-4.14 \%$ stachyose and trace amounts of verbascose.

Studies on metabolizable energy indicated that SBM and dehulled SBM contain about 5-6\% more gross energy than corn; however, they contain 54 and 42\%; respectively, less metabolizable energy than corn (Hill et al., 1960; Hill and Renner, 1960; Potter and Matterson, 1960; Sibbald and Slinger, 1962), indicated that some components of SBM are poorly digested and metabolized. The NRC (1982) suggested energy value for dehulled SBM of 2455 and $3155 \mathrm{ME} \mathrm{kcal} / \mathrm{kg}$ for chicks and pigs, respectively (a difference of approximately $30 \%$ ). This difference between species may be due to innate galactosidase in pigs indicating the potential value of improving carbohydrate fraction utilization for chicks.

The action of NSP in poultry digestive system is essentially a physical one in which plant cell wall either acts as barrier to nutrients release from cell or increase digesta viscosity restricting their absorption (Knudsen, 2001). It also contributes to dropping stickiness, which can cause footpad disorders (Abbott et al., 1969; Jensen et al., 1970). Galactosyl oligosaccharides, known as flatulence-producing factors, are responsible for digestive disorders that influence animal performance (Knudsen, 1997).

Oligo- and poly-saccharides are indigestible to monogastric animals (Iji and Tivey, 1998; Zhang et al., 2001; Park et al., 2003; Selle et al., 2003; Shim et al., 2004). Poultry lack endogenous enzymes targeting $\alpha$-galactosyl bonds $(\alpha-1,6$ galactosidase and $\beta-1,4$ mannanase that target $\alpha-1,6-$ and $\beta-1$, 4-galactosyl bonds, respectively) to digest them (Pluske and Lindemann, 1998). Poor digestibility of oligosaccharide fraction leads to loss of potential energy. Alpha-galactosides have been implicated in reducing energy utilization, fiber digestion and feed retention in SBM-fed chicks (Coon et al., 1990), producing osmotic catharsis (Wagner et al., 1976) and flatus in animals (Leske and Coon, 1999). Various extraction methods and autolysis have been employed in the removal of the $\alpha$-galactosides (Angel et al., 1988;

Fayoum J. Agric. Res. \& Dev., Vol. 30, No.1, January, 2016 
EFFECT OF USING "AVIZYM 1500 " ENZYME ........................ 133

.Leske et al., 1993). However, these techniques are usually expensive and time consuming. Moreover, scientists have been successful in eliminating the principle growth inhibitors in soybeans through physical and chemical processing. This is due to these compounds are heat stable and cannot be eliminated during processing. Applying an exogenous enzyme preparation, mainly composed of $\alpha-1,6$-galactosidase is an alternative to alleviate the detrimental effects of the saccharides (Sugimoto and Van Buren, 1970; Pan et al., 2002).

Therefore, this study was conducted to study the possibility of improving energy and nutrients bioavailability of SBM-based diets fed to Japanese quail (Coturnix coturnix japonica) by dietary addition of "Avizym"1500", an enzymatic preparation containing Amylase, Xylanase, Protease and to test its effect on growth performance, some carcass traits and egg production traits

\section{MATERIALS AND METHODS}

Experimental birds and housing

Two hundred and forty unsexed one-day old Japanese quail chicks with an average body weight of $7.25 \pm 0.07 \mathrm{~g}$ were used in a 42-day growing trial. Chicks were individually wing-banded, weighed, randomly distributed into four equal experimental groups of similar mean weight of 60 chicks each, which consists of three replicates of 20 chicks each. At 42 days of age, birds were transferred to layer quail cages for a 90-day laying trial.

\section{Experimental diets, design and treatments}

Two starter-grower corn-soybean meal (C-SBM) basal diets were formulated to be iso-nitrogenous (24\% CP) and containing 2900 (recommended energy, RE-diet) and 2750 (low energy, LE-diet) kcal ME/kg diet. Also, two C-SBM layer basal diets were formulated to be iso-nitrogenous (20\% CP) and containing 2900 (recommended energy, RE-diet) and 2750 (low energy, LE-diet) $\mathrm{kcal} \mathrm{ME} / \mathrm{kg}$ diet.

A commercial enzyme cocktail preparation, "Avizym 1500", was added at two levels of 0 and $1 \mathrm{~kg} /$ ton diet. Dietary treatments were designed in a $2 \mathrm{x}$ 2 factorial arrangement of two ME levels (2900 and $2750 \mathrm{kcal} / \mathrm{kg}$ diet) and two enzyme levels $(0$ and $1 \mathrm{~kg} / \mathrm{ton}$ of feed). Thus, this supplementation resulted in four dietary treatments in both starting-growing and laying periods. The composition and chemical analysis of the experimental diets are shown in Table (1).

\section{Tested materials}

The commercial enzyme cocktail preparation, "Avizym ${ }^{1500,}$, used in this study was a dried enzyme cocktail preparation that mainly composed of standardized activities of Amylase, Xylanase, Protease enzymes.

Fayoum J. Agric. Res. \& Dev., Vol. 30, No.1, January, 2016 


\section{M.A.A. Abdel-Mageed and E.M. EL-Kamash Management}

During the experimental period, birds were exposed to similar care and management in all treatment groups. Ambient temperature was maintained at 34$36{ }^{\circ} \mathrm{C}$ during the $1^{\text {st }}$ week and was weekly decreased by $4{ }^{\circ} \mathrm{C}$ for the next three weeks. During the $5^{\text {th }}$ and $6^{\text {th }}$ week temperature was maintained at $22-24{ }^{\circ} \mathrm{C}$. Birds were daily received continuous artificial lighting during growing trial and $17 \mathrm{~h}$ afterwards. Chicks were fed the starter-grower diets from one day to six week and the layer diets from seven to 19 week of age. Mash feed and clean fresh tap water were provided ad liblitum.

\section{Measurements and data collection \\ Growth performance:}

Individual body weight (BW, g) and feed intake (FI, g/bird) were weekly recorded to determine body weight gain $(\mathrm{BWG}, \mathrm{g})$ [gain = final weight $(\mathrm{g})$ initial weight $(\mathrm{g})]$. Feed conversion ratio (FCR, g feed/g gain) and caloric conversion ratio (CCR) were also calculated for the starting-growing period.

Performance index (PI) for the starting-growing period, was calculated according the equation reported by North (1981), PI $=[(\mathrm{BW}, \mathrm{kg} / \mathrm{FC}) \times 100]$. Growth rate (GR) for the starting-growing period was also calculated, GR $=[$ (final BW- initial $\mathrm{BW}) / 0.5$ (initial $\mathrm{BW}+$ final $\mathrm{BW})] \times 100$. Mortality rate $\%(\mathrm{MR})$ was also calculated.

\section{Carcass parameters:}

At the end of the starting-growing period (42 days), 24 birds $(3 \hat{\jmath}+3$ q/ treatment) with BW similar to the mean were slaughtered to determine carcass characteristics. Obtained criteria were dressing breast and thighs weights. Abdominal fat was removed from the gizzard and abdominal region and individually weighed for each carcass. Edible giblets (liver, heart, gizzard and total edible giblets) were individually separated, weighed and calculated for each organ as \% of live BW.

\section{Intestinal fluid viscosity:}

At $14 \mathrm{~d}$ of age, two birds per replicate were killed and individual digesta samples were collected from each segment of the intestine (duodenum, jejunum and ileum), weighed and kept on ice before centrifugation at $12,000 \times g$ for 10 $\min$. The supernatant obtained from each sample were separately stored at $-20{ }^{\circ} \mathrm{C}$ until use. The supernatants were thawed and the viscosity of the supernatant $(0.5$ $\mathrm{mL})$, expressed as centipoises $(\mathrm{cP})$, was immediately measured with a digital viscometer.

\section{Volatile fatty acid concentration in the cecum:}

At $21 \mathrm{~d}$ of age, two birds per replicate were killed and cecal content was collected to determine the concentration of acetic, propionic, and butyric acids. Cecal content was diluted with an equal weight of distilled water (Sudo and Duke, 1980) and centrifuged at $25,500 \times g$ for $20 \mathrm{~min}$. A solution of $5 \%$ orthophosphoric acid (vol/vol) plus $1 \%$ mercury chloride (wt/vol) was added $(0.1$ $\mathrm{mL} / \mathrm{mL}$ ) to the supernatant (Garci'a et al., 2000), the mixture was then frozen and stored at $-20{ }^{\circ} \mathrm{C}$ until volatile fatty acids determination.

Fayoum J. Agric. Res. \& Dev., Vol. 30, No.1, January, 2016 
EFFECT OF USING "AVIZYM 1500 " ENZYME....................... 135

Egg production traits:

Daily egg number (EN) and egg weight (EW, g) as well as weekly feed intake (FI, g/bird) was recorded. Egg production (EP, \%), egg mass (EM, g) and feed conversion ratio (FCR, $\mathrm{g}$ feed/g egg) were calculated per each replicate and treatment from seven to 19 weeks of age.

\section{Chemical analysis:}

Experimental diets were analyzed following procedures detailed by the Association of Official Analytical Chemists (AOAC, 1990) for crude protein (CP), crude fiber (CF) and ether extract (EE). Metabolizable energy (ME) of experimental diets was calculated considering the ME values of different feed ingredients according to the Feed Composition Tables for Animal and Poultry Feedstuffs Used in Egypt (2001).

\section{Statistical analysis:}

Obtained data were expressed as means \pm standard error and statistically analyzed by analysis of variance as a factorial arrangement of $2 \times 2$ according to Steel and Torrie (1980). Also, the General Linear Method (GLM) procedure of SPSS (1993) computer statistical program for MS Windows release 6.0 was used. The significant means were ranked using Duncan's Range Test (Duncan, 1955) as outlined by Obi (1990). Statistical significance level was tested at probability of $\mathrm{P} \leq 0.05$.

\section{RESULTS AND DISCUSSION \\ Growth performance:}

The results for live growth performance in terms of final body weight (BW), body weight gain (BWG), feed intake (FI), feed conversion ratio (FCR) and caloric conversion ratio (CCR) during the whole experimental period are shown in Table (2).

With regard to ME levels, it was noticed that feeding RE-diets significantly improved final BW, BWG, FI, FCR and CCR in comparison to LEdiets. Regarding enzymatic preparation, feeding "Avizym ${ }^{1500 "}$-supplemented diets gave significant improvement in BW, BWG, FI, FCR and CCR in comparison to "Avizym ${ }^{1500 "}$-free diets. With respect to the interaction between

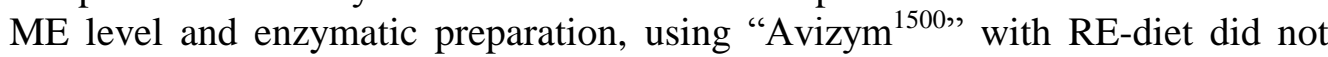
exert any significant effect in BW, BWG, FI, FCR and CCR as compared to the corresponding "Avizym ${ }^{1500 "}$-free diet. On the other hand, supplementing "Avizym 1500," to LE-diet gave equal performance to the corresponding "Avizym ${ }^{1500 ", ~-f r e e ~ d i e t . ~}$

The present study indicated that the improved values of BW in case of

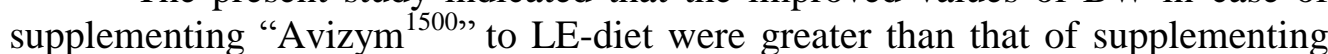

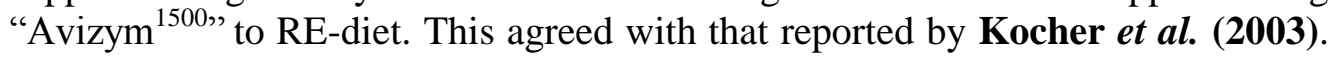
Moreover, Cowan et al. (1996) mentioned that enzyme supplementation to low nutrient level diets had greater beneficial effect than supplementation to high nutrient level diets. This will be practicable for producers to reduce the apparent metabolizable energy of diets by 3 to $4 \%$ in feed formulas and therefore has a cost benefit. The improvement in BWG and FCR in this study is in agreement with

Fayoum J. Agric. Res. \& Dev., Vol. 30, No.1, January, 2016 

found that the addition of $\beta$-mannanase significantly improved the BWG and FCR of male broilers during starter and grower phases, indicating that the improvement in FCR can mainly be attributed to energy utilization and perhaps changes in intestinal viscosity.

However, these results are in disagreement with the findings of Waldroup et al. (2006) who found a lack of improvement in growth performance of broiler chickens fed $\alpha$-galactosidase-supplemented diets and those of Irish $\boldsymbol{e t}$ al. (1995) who demonstrated that the addition of $\alpha$-galactosidases did not significantly improve FCR in broilers. In other studies, the inclusion of commercial enzyme complexes containing multicarbohydrase activities did not produce an improvement in growth performance of birds fed SBM-based diets (Marsman et al., 1997).

\section{Performance index, growth rate and mortality rate:}

The mean values of PI, GR values as well as MR \% are given in Table (3). Regarding ME levels, it was observed that feeding RE-diets resulted in significant increase in PI and GR and significant decrease in MR \% as compared to LE-diets. Concerning enzymatic preparation, feeding "Avizym ${ }^{1500 "}$ "-supplemented diets gave significant improvement in PI and GR and significant decrease in MR \% in comparison to "Avizym ${ }^{1500 "}$ "-free diets. With respect to the interaction between

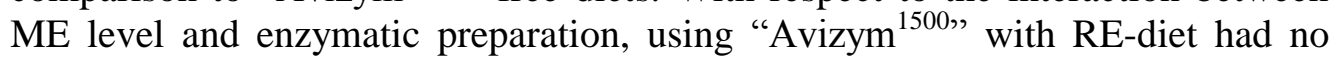
significant effect on PI and GR, whereas it significantly decreased MR \% as compared to the corresponding "Avizym ${ }^{1500 "}$ "free diet. While, supplementing "Avizym ${ }^{1500, " ~ t o ~ L E-d i e t ~ s i g n i f i c a n t l y ~ i m p r o v e d ~ P I ~ a n d ~ G R, ~ w h e r e a s ~ i t ~}$ significantly decreased MR \% as compared to the corresponding "Avizym"1500", free diet.

The improvement in GR in this study is in disagreement with those results reported by Irish et al. (1995) who demonstrated that the addition of $\alpha$ galactosidases did not significantly improve GR in broilers.

\section{Carcass parameters}

The percentage of dressing, breast, thighs and abdominal fat are summarized in Table (4).

With regard to ME levels, it was noticed that feeding RE-diets caused significant increase in carcass parameters, the only exception was for abdominal fat that did not significantly differ as compared to LE-diets. Regarding enzymatic preparation, feeding "Avizym ${ }^{1500 "}$ "-supplemented diets gave significant increase in dressing, breast and thighs $\%$ as well as significant decrease in abdominal fat $\%$

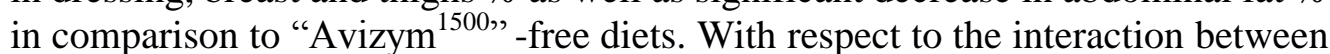
ME level and enzymatic preparation, using "Avizym ${ }^{1500 "}$, with NE-diet did not exert any significant effect in carcass parameters \% except for abdominal fat $\%$ that was significantly decreased as compared to the corresponding "Avizym" ${ }^{1500 "}$ " free diet. However, supplementing "Avizym ${ }^{1500 "}$ to LE-diet had significantly increased carcass parameters $\%$, but it significantly decreased abdominal fat $\%$ as compared to the corresponding "Avizym" ${ }^{1500 "}$ "-free diet.

Fayoum J. Agric. Res. \& Dev., Vol. 30, No.1, January, 2016 
EFFECT OF USING "AVIZYM 1500 " ENZYME. 137

The present result of improving breast yield agreed well with the findings that reported by Lamptey et al. (2001) and Abdel-Mageed et al., (2013) but it was in disagreement with these found by Kidd et al. (2001) who demonstrated that diets containing $\alpha$-galactosidase have no effect on breast meat yield. This discrepancy may be due to the different $\alpha$-galactosidase characterization and rearing environment. The improvement of breast yield may be interpreted by the utilization of nutrients liberated from the non-digestible compounds of corn and soybean meal diet with $\alpha$-galactosidase.

\section{Edible giblets:}

Percentages of edible giblets in terms of liver, heart, gizzard and total edible giblets at $6 \mathrm{wk}$ of age are given in Table (5).

Regarding ME levels, it was noticed that feeding RE-diets caused significantly increased each of liver, heart and total edible giblets \% in comparison to LE-diets. Concerning enzymatic preparation, feeding "Avizym ${ }^{1500 "}$ " -supplemented diets gave significant increase in liver, heart and total edible giblets \% in comparison to LE-diets. There was no significant response obtained for ME levels, enzyme supplementation or their interaction on gizzard \%. With respect to the interaction between ME level and enzymatic preparation, using "Avizym ${ }^{1500}$ " with RE-diet diet did not cause significant change in liver, heart and edible giblets $\%$ as compared to the corresponding "Avizym ${ }^{1500 \text { " }}$-free diet. However, supplementing "Avizym ${ }^{1500 "}$ " to LE-diet had significantly increased liver, heart and edible giblets $\%$ as compared to the corresponding "Avizym ${ }^{1500 "}$ "-free diet. This agreed with that reported by Abdel-Mageed et al. (2013).

The aforementioned reduction of the relative weights of liver and heart are in disagreement with the results of Tahir $\boldsymbol{e t}$ al. (2005) who showed that enzyme treatments did not affect the relative weight of liver. Gracia et al. (2003) reported that enzyme has no effect on the relative weights of digestive organs.

The lack of response in relative weight of gizzard is in disagreement with the results of Brenes $\boldsymbol{e t}$ al. (1993) who found that the relative weight of gizzard was reduced by enzyme treatment.

\section{Intestinal fluid viscosity:}

The mean values of viscosity in different parts of intestine and incidence of pasting vents at seven and 14 days of age are presented in Table (6).

With regard to ME levels, it was noticed that feeding both levels did not exert any significant effect in the viscosity in different parts of intestine; however it significantly increased the pasting vents \% for RE-diets as compared with LEdiets.

With respect to enzymatic preparation, feeding "Avizym"1500" supplemented diets significantly decreased the viscosity in different parts of

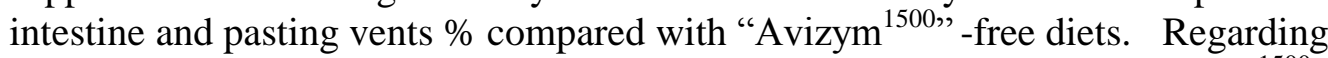
the interaction between ME level and enzymatic preparation, using "Avizym ${ }^{1500}$, with either RE- or LE-diet significantly decreased the viscosity in different parts of intestine and pasting vents \% compared with the corresponding "Avizym ${ }^{1500,}$. free diet.

Fayoum J. Agric. Res. \& Dev., Vol. 30, No.1, January, 2016 
Increasing viscosity of intestinal fluid inhibits the absorption of nutrients by decreasing the gastrointestinal passage rate. In other words, Enzymes supplementation act to decrease the viscosity of intestinal fluid, which results in improving the digestion and absorption process by increasing the gastrointestinal passage rate and increasing the diffusion of digestive enzymes and the secretion of endogenous enzymes (Van der Klis et al., 1993 and Abdel-Mageed et al., (2013).

\section{Volatile fatty acid concentration in cecum}

Percentages of volatile fatty acid (VFA) in terms of acetic acid, propionic acid, butyric acid as well as the total VFA concentration in cecum at quail at $6 \mathrm{wk}$ of age are shown in Table (7).

Regarding ME levels, it was noticed that feeding RE-diets did not exert any significant effect in the percentages of acetic acid, butyric acid as well as the total VFA concentration compared with LE-diets. No significant responses was obtained for each of ME levels, enzyme supplementation or the interaction between ME level and enzymatic preparation in propionic acid \%. With respect to enzymatic preparation, feeding "Avizym ${ }^{1500 "}$ " -supplemented diets significantly increased the percentages of acetic acid, butyric acid as well as the total VFA concentration compared with "Avizym ${ }^{1500 "}$ "free diets. Regarding the interaction

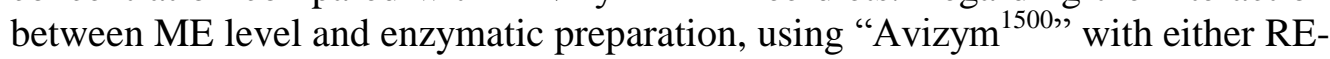
or LE-diet significantly increased percentages of acetic acid, butyric acid as well as the total VFA concentration compared with the corresponding "Avizym"1500". free diet.

\section{Laying performance:}

Results concerning laying performance in terms of feed intake (FI), egg production (EP) \%, egg number (EN), egg weight (EW), egg mass (EM) and feed conversion ratio (FCR) values are shown in Table (8).

With regard to ME levels, it was noticed that feeding RE-diets caused significant increase in EP \%, EN, EW, EM and better FCR, but it significantly decreased FI compared with LE-diets. With respect to enzymatic preparation, feeding "Avizym ${ }^{1500 ", ~-s u p p l e m e n t e d ~ d i e t s ~ s i g n i f i c a n t l y ~ i m p r o v e d ~ E P ~ \%, ~ E N, ~ E W, ~ E M ~}$

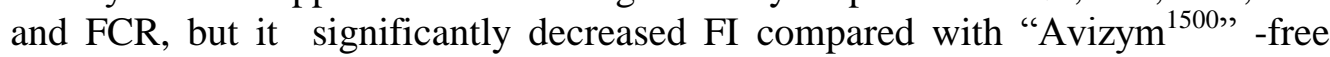
diets. Regarding the interaction between ME level and enzymatic preparation, using "Avizym "1500" with RE-diet did not exert any significant effect in FI, EP \%, EN, EW, EM and FCR compared with the corresponding "Avizym ${ }^{1500 "}$ "-free diet.

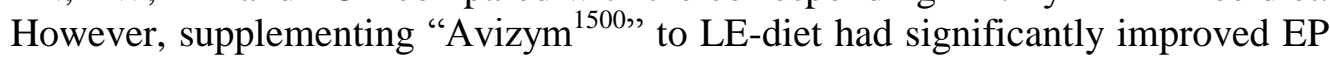
$\%$, EN, EW, EM and FCR, but it significantly decreased FI as compared to the corresponding "Avizym ${ }^{1500 "}$-free diet. This agreed with that reported by AbdelMageed et al. (2013).

In conclusion, this study provides some evidence that exogenous Amylase, Xylanase, Protease may improve energy extraction from SBM by Japanese quail (Coturnix coturnix japonica). From the nutritional point of view, it

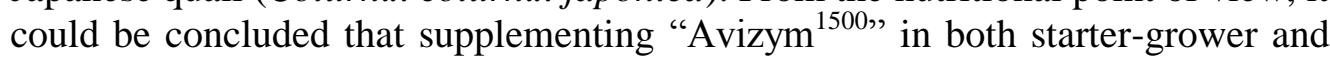

Fayoum J. Agric. Res. \& Dev., Vol. 30, No.1, January, 2016 
EFFECT OF USING "AVIZYM"1500" ENZYME.

layer diets at a level of $0.1 \%$ helped in improving quail performance, carcass traits and egg production traits.

Table (1): Composition and calculated analysis of the experimental starter-grower and layer basal diets.

\begin{tabular}{|c|c|c|c|c|}
\hline \multirow{3}{*}{ Ingredients } & \multicolumn{4}{|c|}{ Percentage (\%) } \\
\hline & \multicolumn{2}{|c|}{ Starter-grower basal diets } & \multicolumn{2}{|c|}{ Layer basal diets ${ }^{*}$} \\
\hline & RE-diet & LE-diet & RE-diet & LE-diet \\
\hline Yellow Corn, ground & 54.27 & 50.64 & 58.45 & 53.70 \\
\hline Soybean meal (44\% CP) & 35.00 & 38.23 & 25.80 & 27.34 \\
\hline Corn gluten meal (62\% CP) & 7.14 & 4.37 & 6.70 & 4.90 \\
\hline Wheat bran & 0.00 & 3.80 & 0.00 & 5.30 \\
\hline Vegetable oil & 0.50 & 0.00 & 1.30 & 1.10 \\
\hline Dicalcium phosphate & 0.75 & 0.70 & 1.10 & 1.05 \\
\hline Limestone & 1.35 & 1.35 & 5.70 & 5.70 \\
\hline Common salt (NaCl) & 0.34 & 0.34 & 0.34 & 0.34 \\
\hline Premix $^{* * *}$ & 0.30 & 0.30 & 0.30 & 0.30 \\
\hline DL-Methionine & 0.04 & 0.07 & 0.05 & 0.07 \\
\hline L-Lysine & 0.11 & 0.00 & 0.06 & 0.00 \\
\hline Choline chloride & 0.20 & 0.20 & 0.20 & 0.20 \\
\hline Total & 100.00 & 100.00 & 100.00 & 100.00 \\
\hline \multicolumn{5}{|l|}{ Determined values (\%) } \\
\hline CP \% & 24.01 & 24.00 & 20.01 & 20.00 \\
\hline CF \% & 3.95 & 4.46 & 3.36 & 3.91 \\
\hline EE \% & 2.74 & 2.61 & 2.76 & 2.58 \\
\hline \multicolumn{5}{|l|}{ Calculated values $^{* * * *}$} \\
\hline ME (kcal/kg) & 2903 & 2759 & 2890 & 2750 \\
\hline $\mathrm{Ca} \%$ & 0.80 & 0.80 & 2.50 & 2.50 \\
\hline Av. Phosphorus \% & 0.30 & 0.30 & 0.35 & 0.35 \\
\hline L-Lysine \% & 1.30 & 1.30 & 1.00 & 1.01 \\
\hline DL-Methionine \% & 0.50 & 0.50 & 0.45 & 0.45 \\
\hline Methionine + Cyst \% & 1.00 & 1.00 & 0.80 & 0.84 \\
\hline
\end{tabular}

*Starter-grower and layer basal diets were assigned to 2 levels of "Avizym" ${ }^{1500 "}$ enzyme preparation $(0 \& 1 \mathrm{~kg} /$ ton diet $)$.

**Vitamins and minerals premix provides per kg of diet: $10000 \mathrm{IU}$ vit. A, $11.0 \mathrm{IU}$ vit. E, 1.1 $\mathrm{mg}$ vit. $\mathrm{K}, 1100 \mathrm{ICU}$ vit. $\mathrm{D}_{3}, 5 \mathrm{mg}$ riboflavin, $12 \mathrm{mg}$ Ca pantothenate, $12.1 \mu \mathrm{g}$ vit. $\mathrm{B}_{12}, 2.2 \mathrm{mg}$ vit. $\mathrm{B}_{6}, 2.2 \mathrm{mg}$ thiamin, $44 \mathrm{mg}$ nicotinic acid, $250 \mathrm{mg}$ choline chloride, $1.55 \mathrm{mg}$ folic acid, $0.11 \mathrm{mg}$ d-biotin, $60 \mathrm{mg} \mathrm{Mn,} 50 \mathrm{mg} \mathrm{Zn}, 0.3 \mathrm{mg} \mathrm{I}, 0.1 \mathrm{mg} \mathrm{Co}, 30 \mathrm{mg} \mathrm{Fe}, 5 \mathrm{mg} \mathrm{Cu}$ and $1 \mathrm{mg}$ Se.

***According to Feed Composition Tables for animal and poultry feedstuffs used in Egypt (2001).

Fayoum J. Agric. Res. \& Dev., Vol. 30, No.1, January, 2016 
Table (2): Effect of dietary treatments on performance of growing Japanese quail during the period from $0-6$ weeks of age.

\begin{tabular}{|c|c|c|c|c|c|c|}
\hline $\begin{array}{c}\text { Items } \\
\text { Treatments }(24 \% \\
\text { CP) }\end{array}$ & $\begin{array}{c}\text { Initial } \\
\text { BW } \\
\text { (g/bird) }\end{array}$ & $\begin{array}{c}\text { Final } \\
\text { BW } \\
\text { (g/bird) }\end{array}$ & $\begin{array}{c}\text { BWG } \\
\text { (g/bird/35 d) }\end{array}$ & $\begin{array}{c}\text { FI } \\
\text { (g/bird/35 d) }\end{array}$ & $\begin{array}{c}\text { FCR } \\
\text { (Feed: } \\
\text { gain) }\end{array}$ & $\begin{array}{c}\text { CCR } \\
\text { (Calorie: } \\
\text { gain) } \\
\end{array}$ \\
\hline \multicolumn{7}{|c|}{ Energy effects } \\
\hline 2900 (kcal/kg diet) & $7.24 \pm 0.07$ & $197.42 \pm 1.34^{\mathrm{a}}$ & $190.18 \pm 1.10^{\mathrm{a}}$ & $446.08 \pm 3.05^{b}$ & $2.35 \pm 0.08^{b}$ & $6.46 \pm 0.04^{b}$ \\
\hline 2750 (kcal/ & $7.25 \pm 0.11$ & $184.04 \pm 1.42^{\mathrm{b}}$ & $176.79 \pm 1.09^{\mathrm{b}}$ & $469.02 \pm 2.90^{\mathrm{a}}$ & $2.65 \pm 0.05^{\mathrm{a}}$ & $7.28 \pm 0.05^{\mathrm{a}}$ \\
\hline \multicolumn{7}{|c|}{ Enzyme effects } \\
\hline $\begin{array}{c}\text { Avizym }^{1500} \\
\text { (0.0kg/kg diet) }\end{array}$ & $7.23 \pm 0.09$ & $184.29 \pm 1.25^{\mathrm{b}}$ & $177.06 \pm 1.15^{b}$ & $466.57 \pm 2.23^{\mathrm{a}}$ & $2.64 \pm 0.06^{\mathrm{a}}$ & $7.45 \pm 0.09^{\mathrm{a}}$ \\
\hline $\begin{array}{c}\text { Avizym } \\
(0.1 \mathrm{~kg} / \mathrm{kg} \text { diet })\end{array}$ & $7.27 \pm 0.06$ & $197.17 \pm 1.41^{\mathrm{a}}$ & $189.90 \pm 1.22^{\mathrm{a}}$ & $448.54 \pm 2.11^{b}$ & $2.36 \pm 0.11^{b}$ & $6.66 \pm 0.11^{b}$ \\
\hline \multicolumn{7}{|c|}{ Interaction } \\
\hline 2900 & $7.22 \pm 0.05$ & $195.36 \pm 1.14^{\mathrm{a}}$ & $188.14 \pm 1.13^{\mathrm{a}}$ & $450.10 \pm 2.21^{b}$ & $2.39 \pm 0.11^{b}$ & $6.93 \pm 0.09^{b}$ \\
\hline 2900 & $7.28 \pm 0.08$ & $199.48 \pm 1.10^{\mathrm{a}}$ & $192.20 \pm 1.05^{\mathrm{a}}$ & $442.06 \pm 2.17^{b}$ & $2.30 \pm 0.06^{b}$ & $6.67 \pm 0.04^{b}$ \\
\hline $2750 \times 0.0$ & $7.24 \pm 0.06$ & $173.21 \pm 1.12^{\mathrm{b}}$ & $165.97 \pm 1.14^{\mathrm{b}}$ & $483.03 \pm 3.04^{\mathrm{a}}$ & $2.91 \pm 0.10^{\mathrm{a}}$ & $8.00 \pm 0.07^{\mathrm{a}}$ \\
\hline $2750 \times 0.1$ & $7.26 \pm 0.04$ & $194.86 \pm 1.11^{\mathrm{a}}$ & $187.60 \pm 1.07^{\mathrm{a}}$ & $455.01 \pm 2.18^{b}$ & $2.43 \pm 0.12^{\mathrm{b}}$ & $6.68 \pm 0.04^{b}$ \\
\hline
\end{tabular}

Means in the same column within the same effect having different letters are significantly different at $\mathrm{P} \leq 0.05$.

$$
\begin{array}{lll} 
& \mathrm{BW}=\text { Body weight } \quad \mathrm{BWG}=\text { Body weight gain } & \mathrm{FI}=\text { Feed } \\
\text { intake } & \mathrm{FCR}=\text { Feed conversion ratio } &
\end{array}
$$

$\mathrm{CCR}=$ caloric conversion ratio

Table (3): Effect of dietary treatments on performance index, growth rate

\begin{tabular}{|c|c|c|c|}
\hline $\begin{array}{c}\text { Items } \\
\text { Treatments }(24 \% \mathrm{CP})\end{array}$ & PI & GR & $\begin{array}{l}\text { MR } \\
(\%)\end{array}$ \\
\hline \multicolumn{4}{|c|}{ Energy effects } \\
\hline 2900 (kcal/kg diet) & $7.67 \pm 0.11^{\mathrm{a}}$ & $186.65 \pm 0.13^{\mathrm{a}}$ & $6.05 \pm 0.03^{b}$ \\
\hline 2750 (kcal/kg diet) & $6.73 \pm 0.12^{\mathrm{b}}$ & $185.56 \pm 0.21^{b}$ & $8.56 \pm 0.05^{\mathrm{a}}$ \\
\hline \multicolumn{4}{|c|}{ Enzyme effects } \\
\hline $\begin{array}{c}\operatorname{Avizym}^{1500}(0.0 \mathrm{~kg} / \mathrm{kg} \\
\text { diet })\end{array}$ & $6.78 \pm 0.08^{b}$ & $185.61 \pm 0.12^{b}$ & $10.22 \pm 0.06^{\mathrm{a}}$ \\
\hline $\begin{array}{c}\text { Avizym } \\
\text { diet })\end{array}$ & $7.61 \pm 0.05^{\mathrm{a}}$ & $186.59 \pm 0.10^{\mathrm{a}}$ & $4.39 \pm 0.05^{b}$ \\
\hline \multicolumn{4}{|c|}{ Interaction } \\
\hline $2900 \times 0.0$ & $7.83 \pm 0.06^{\mathrm{a}}$ & $186.55 \pm 0.15^{\mathrm{a}}$ & $8.55 \pm 0.05^{b}$ \\
\hline $2900 \times 0.1$ & $7.50 \pm 0.11^{\mathrm{a}}$ & $186.74 \pm 0.13^{\mathrm{a}}$ & $3.55 \pm 0.06^{\mathrm{d}}$ \\
\hline $2750 \times 0.0$ & $5.73 \pm 0.12^{b}$ & $184.67 \pm 0.07^{b}$ & $11.89 \pm 0.04^{\mathrm{a}}$ \\
\hline $2750 \times 0.1$ & $7.72 \pm 0.11^{\mathrm{a}}$ & $186.44 \pm 0.23^{\mathrm{a}}$ & $5.22 \pm 0.03^{\mathrm{c}}$ \\
\hline
\end{tabular}
and mortality rate of Japanese quail at 0 - 6 weeks of age.

Means in the same column within the same effect having different letters are significantly different at $\mathrm{P} \leq 0.05$.

$\mathrm{PI}=$ Performance index $\quad$ GR $=$ Growth rat $\quad \mathrm{MR}=$ mortality rate

Fayoum J. Agric. Res. \& Dev., Vol. 30, No.1, January, 2016 
EFFECT OF USING "AVIZYM" 1500 " ENZYME........................ 141

Table (4): Effect of dietary treatments on carcass characteristics of Japanese quail at 6 weeks of age.

\begin{tabular}{|c|c|c|c|c|}
\hline \multirow{2}{*}{$\begin{array}{c}\text { Items } \\
\text { Treatments }(24 \% \mathrm{CP})\end{array}$} & \multicolumn{4}{|c|}{$(\%$ of $\mathrm{BW})$} \\
\hline & Dressing ${ }^{*}$ & Breast & Thighs & Abdominal fat \\
\hline \multicolumn{5}{|c|}{ Energy effects } \\
\hline 2900 (kcal/kg diet) & $77.99 \pm 0.40^{\mathrm{a}}$ & $38.77 \pm 0.33^{\mathrm{a}}$ & $24.94 \pm 0.12^{\mathrm{a}}$ & $1.35 \pm 0.02$ \\
\hline 2750 (kcal/kg diet) & $76.50 \pm 0.28^{b}$ & $36.90 \pm 0.21^{\mathrm{b}}$ & $23.21 \pm 0.11^{b}$ & $1.36 \pm 0.01$ \\
\hline \multicolumn{5}{|c|}{ Enzyme effects } \\
\hline $\operatorname{Avizym}^{1500}(0.0 \mathrm{~kg} / \mathrm{kg}$ diet $)$ & $76.16 \pm 0.32^{b}$ & $36.60 \pm 0.42^{b}$ & $23.01 \pm 0.11^{\mathrm{b}}$ & $1.42 \pm 0.02^{\mathrm{a}}$ \\
\hline $\operatorname{Avizym}^{1500}(0.1 \mathrm{~kg} / \mathrm{kg}$ diet $)$ & $78.33 \pm 0.11^{\mathrm{a}}$ & $39.07 \pm 0.11^{\mathrm{a}}$ & $25.14 \pm 0.13^{\mathrm{a}}$ & $1.30 \pm 0.01^{\mathrm{b}}$ \\
\hline \multicolumn{5}{|c|}{ Interaction } \\
\hline $2900 \times 0.0$ & $77.45 \pm 0.23^{\mathrm{a}}$ & $38.33 \pm 0.34^{\mathrm{a}}$ & $24.81 \pm 0.11^{\mathrm{a}}$ & $1.42 \pm 0.02^{\mathrm{a}}$ \\
\hline $2900 \times 0.1$ & $78.52 \pm 0.36^{\mathrm{a}}$ & $39.20 \pm 0.28^{\mathrm{a}}$ & $25.06 \pm 0.13^{\mathrm{a}}$ & $1.28 \pm 0.01^{\mathrm{b}}$ \\
\hline $2750 \times 0.0$ & $74.87 \pm 0.15^{b}$ & $34.86 \pm 0.45^{b}$ & $21.20 \pm 0.10^{\mathrm{b}}$ & $1.41 \pm 0.01^{\mathrm{a}}$ \\
\hline $2750 \times 0.1$ & $78.13 \pm 0.33^{\mathrm{a}}$ & $38.94 \pm 0.14^{\mathrm{a}}$ & $25.22 \pm 0.13^{\mathrm{a}}$ & $1.31 \pm 0.02^{\mathrm{b}}$ \\
\hline
\end{tabular}

$*$ Dressing $\%=[($ Carcass weight + Giblets weight $) /($ Pre-slaughter weight $)] \times 100$.

Means in the same column within the same effect having different letters are significantly different at $\mathrm{P} \leq 0.05$.

Table (5): Effect of dietary treatments on edible giblets \% of Japanese quail at 6 weeks of age.

\begin{tabular}{|c|c|c|c|c|}
\hline \multirow{2}{*}{$\begin{array}{c}\text { Items } \\
\text { Treatments }(24 \% \mathrm{CP})\end{array}$} & \multicolumn{3}{|c|}{ Edible giblets (\%) } & \multirow{2}{*}{$\begin{array}{l}\text { Total edible } \\
\text { giblets } \\
(\%)\end{array}$} \\
\hline & $\begin{array}{l}\text { Liver } \\
(\%)\end{array}$ & $\begin{array}{c}\text { Heart } \\
(\%)\end{array}$ & $\begin{array}{c}\text { Gizzard } \\
(\%)\end{array}$ & \\
\hline \multicolumn{5}{|c|}{ Energy effects } \\
\hline 2900 (kcal/kg diet) & $2.72 \pm 0.13^{\mathrm{a}}$ & $1.66 \pm 0.08^{\mathrm{a}}$ & $2.24 \pm 0.12$ & $6.62 \pm 0.13^{\mathrm{a}}$ \\
\hline 2750 (kcal/kg diet) & $2.37 \pm 0.11^{b}$ & $1.44 \pm 0.06^{\mathrm{b}}$ & $2.29 \pm 0.11$ & $6.10 \pm 0.11^{\mathrm{b}}$ \\
\hline \multicolumn{5}{|c|}{ Enzyme effects } \\
\hline Avizym $^{1500}(0.0 \mathrm{~kg} / \mathrm{kg}$ diet $)$ & $2.38 \pm 0.06^{b}$ & $1.45 \pm 0.11^{b}$ & $2.25 \pm 0.11$ & $6.08 \pm 0.12^{\mathrm{b}}$ \\
\hline $\operatorname{Avizym}^{1500}(0.1 \mathrm{~kg} / \mathrm{kg}$ diet $)$ & $2.70 \pm 0.10^{\mathrm{a}}$ & $1.65 \pm 0.08^{\mathrm{a}}$ & $2.29 \pm 0.08$ & $6.64 \pm 0.10^{\mathrm{a}}$ \\
\hline \multicolumn{5}{|c|}{ Interaction } \\
\hline $2900 \times 0.0$ & $2.65 \pm 0.10^{\mathrm{a}}$ & $1.68 \pm 0.05^{\mathrm{a}}$ & $2.22 \pm 0.12$ & $6.55 \pm 0.13^{\mathrm{a}}$ \\
\hline $2900 \times 0.1$ & $2.78 \pm 0.06^{\mathrm{a}}$ & $1.63 \pm 0.07^{\mathrm{a}}$ & $2.26 \pm 0.10$ & $6.67 \pm 0.11^{\mathrm{a}}$ \\
\hline $2750 \times 0.0$ & $2.11 \pm 0.09^{b}$ & $1.22 \pm 0.11^{b}$ & $2.27 \pm 0.11$ & $5.60 \pm 0.12^{b}$ \\
\hline $2750 \times 0.1$ & $2.62 \pm 0.13^{\mathrm{a}}$ & $1.66 \pm 0.05^{\mathrm{a}}$ & $2.31 \pm 0.06$ & $6.59 \pm 0.11^{\mathrm{a}}$ \\
\hline
\end{tabular}

Means in the same column within the same effect having different letters are Significantly different at $\mathrm{P} \leq 0.05$.

Fayoum J. Agric. Res. \& Dev., Vol. 30, No.1, January, 2016 
M.A.A. Abdel-Mageed and E.M. EL-Kamash

Table (6): Effect of dietary treatments on intestinal viscosity and incidence of pasting vents of Japanese quail at 14 days of age.

\begin{tabular}{|c|c|c|c|c|}
\hline \multirow[t]{3}{*}{ Items } & \multirow{2}{*}{\multicolumn{3}{|c|}{$\begin{array}{c}\text { Intestinal viscosity }(\mathrm{cP}) \\
\text { Day } 14 \\
\end{array}$}} & \multirow{3}{*}{$\begin{array}{c}\text { Pasting vents } \\
(\%)\end{array}$} \\
\hline & & & & \\
\hline & Duodenum & Jejunum & Ileum & \\
\hline \multicolumn{5}{|c|}{ Energy effects } \\
\hline 2900 (kcal/kg diet) & $2.24 \pm 0.08$ & $4.94 \pm 0.16$ & $4.10 \pm 0.11$ & $16.89 \pm 0.21^{\mathrm{a}}$ \\
\hline 2750 (kcal/kg diet) & $2.18 \pm 0.07$ & $4.68 \pm 0.11$ & $4.12 \pm 0.08$ & $11.34 \pm 0.30^{\mathrm{b}}$ \\
\hline \multicolumn{5}{|c|}{ Enzyme effects } \\
\hline $\begin{array}{c}\text { Avizym }^{1500}(0.0 \mathrm{~kg} / \mathrm{kg} \\
\text { diet })\end{array}$ & $2.73 \pm 0.10^{\mathrm{a}}$ & $5.55 \pm 0.13^{\mathrm{a}}$ & $4.61 \pm 0.13^{\mathrm{a}}$ & $19.67 \pm 0.23^{\mathrm{a}}$ \\
\hline $\begin{array}{c}\text { Avizym }^{1500}(0.1 \mathrm{~kg} / \mathrm{kg} \\
\text { diet })\end{array}$ & $1.72 \pm 0.05^{\mathrm{b}}$ & $4.07 \pm 0.18^{b}$ & $3.61 \pm 0.11^{b}$ & $8.56 \pm 0.26^{b}$ \\
\hline \multicolumn{5}{|c|}{ Interaction } \\
\hline $2900 \times 0.0$ & $2.82 \pm 0.04^{\mathrm{a}}$ & $5.63 \pm 0.12^{\mathrm{a}}$ & $4.67 \pm 0.13^{\mathrm{a}}$ & $22.44 \pm 0.12^{\mathrm{a}}$ \\
\hline $2900 \times 0.1$ & $1.66 \pm 0.02^{b}$ & $4.24 \pm 0.10^{b}$ & $3.53 \pm 0.10^{b}$ & $11.33 \pm 0.30^{c}$ \\
\hline $2750 \times 0.0$ & $2.63 \pm 0.04^{\mathrm{a}}$ & $5.46 \pm 0.15^{\mathrm{a}}$ & $4.55 \pm 0.11^{\mathrm{a}}$ & $16.89 \pm 0.20^{\mathrm{b}}$ \\
\hline $2750 \times 0.1$ & $1.72 \pm 0.05^{\mathrm{b}}$ & $3.90 \pm 0.11^{\mathrm{b}}$ & $3.69 \pm 0.14^{b}$ & $5.78 \pm 0.33^{d}$ \\
\hline
\end{tabular}

Means in the same column within the same effect having different letters are significantly different at $\mathrm{P} \leq 0.05$

Table (7): Effect of dietary treatments on volatile fatty acid (VFA) concentration in cecum of growing Japanese quail at $21 \mathrm{~d}$ of age.

\begin{tabular}{|c|c|c|c|c|}
\hline Treatments (24\% CP) & $\begin{array}{l}\text { Acetic } \\
\text { acid } \\
(\%)\end{array}$ & $\begin{array}{c}\text { Propionic } \\
\text { acid } \\
(\%)\end{array}$ & $\begin{array}{c}\text { Butyric } \\
\text { acid } \\
(\%)\end{array}$ & $\begin{array}{c}\text { Total } \\
\text { VFA } \\
(\mu \mathrm{mol} / \mathrm{g})\end{array}$ \\
\hline \multicolumn{5}{|c|}{ Energy effects } \\
\hline 2900 (kcal/kg diet) & $69.71 \pm 0.21$ & $3.60 \pm 0.06$ & $11.73 \pm 0.12$ & $16.69 \pm 0.22$ \\
\hline 2750 (kcal/kg diet) & $70.97 \pm 0.17$ & $3.61 \pm 0.11$ & $12.02 \pm 0.11$ & $16.82 \pm 0.20$ \\
\hline \multicolumn{5}{|c|}{ Enzyme effects } \\
\hline $\operatorname{Avizym}^{1500}(0.0 \mathrm{~kg} / \mathrm{kg}$ diet $)$ & $68.52 \pm 0.11^{\mathrm{b}}$ & $3.69 \pm 0.07$ & $10.64 \pm 0.12^{b}$ & $15.37 \pm 0.22^{b}$ \\
\hline $\operatorname{Avizym}^{1500}(0.1 \mathrm{~kg} / \mathrm{kg}$ diet $)$ & $72.16 \pm 0.15^{\mathrm{a}}$ & $3.52 \pm 0.05$ & $13.11 \pm 0.10^{\mathrm{a}}$ & $18.14 \pm 0.21^{\mathrm{a}}$ \\
\hline \multicolumn{5}{|c|}{ Interaction } \\
\hline $2900 \times 0.0$ & $68.34 \pm 0.13^{b}$ & $3.74 \pm 0.08$ & $10.52 \pm 0.13^{b}$ & $15.32 \pm 0.21^{\mathrm{b}}$ \\
\hline $2900 \times 0.1$ & $71.08 \pm 0.18^{\mathrm{a}}$ & $3.45 \pm 0.07$ & $12.93 \pm 0.11^{\mathrm{a}}$ & $18.06 \pm 0.22^{\mathrm{a}}$ \\
\hline $2750 \times 0.0$ & $68.70 \pm 0.12^{\mathrm{b}}$ & $3.63 \pm 0.05$ & $10.76 \pm 0.12^{b}$ & $15.41 \pm 0.20^{\mathrm{b}}$ \\
\hline $2750 \times 0.1$ & $73.24 \pm 0.15^{\mathrm{a}}$ & $3.58 \pm 0.07$ & $13.28 \pm 0.12^{\mathrm{a}}$ & $18.22 \pm 0.23^{\mathrm{a}}$ \\
\hline
\end{tabular}

Means in the same column within the same effect having different letters are significantly different at $\mathrm{P} \leq 0.05$

Fayoum J. Agric. Res. \& Dev., Vol. 30, No.1, January, 2016 
EFFECT OF USING "AVIZYM 1500 " ENZYME. 143

Table (8): Effect of dietary treatments on performance of laying Japanese quail from 7 to 19 weeks of age.

\begin{tabular}{|c|c|c|c|c|c|c|}
\hline Items & & & & & & \\
\hline $\begin{array}{l}\text { Treatments } \\
(20 \% \text { CP })\end{array}$ & $\begin{array}{c}\text { FI } \\
\text { (g/hen/day) }\end{array}$ & $\begin{array}{l}\text { EP } \\
(\%)\end{array}$ & $\begin{array}{c}\text { EN } \\
\text { (No./hen/day) }\end{array}$ & $\begin{array}{c}\text { EW } \\
(\mathrm{g})\end{array}$ & $\begin{array}{c}\text { EM } \\
\text { (g/hen/day) }\end{array}$ & $\begin{array}{c}\text { FCR } \\
\text { (g feed/g egg) }\end{array}$ \\
\hline \multicolumn{7}{|c|}{ Energy effects } \\
\hline 2900 (kcal/kg diet) & $23.96 \pm 0.05^{\mathrm{b}}$ & $82.88 \pm 0.38^{\mathrm{a}}$ & $0.95 \pm 0.02^{\mathrm{a}}$ & $11.38 \pm 0.01^{\mathrm{a}}$ & $9.31 \pm 0.02^{\mathrm{a}}$ & $2.83 \pm 0.02^{b}$ \\
\hline 2750 (kcal/kg diet) & $26.18 \pm 0.10^{\mathrm{a}}$ & $80.21 \pm 0.71^{b}$ & $0.92 \pm 0.01^{b}$ & $10.76 \pm 0.02^{b}$ & $8.55 \pm 0.01^{b}$ & $3.37 \pm 0.01^{\mathrm{a}}$ \\
\hline \multicolumn{7}{|c|}{ Enzyme effects } \\
\hline $\begin{array}{c}\text { Avizym }^{1500} \\
(0.0 \mathrm{~kg} / \mathrm{kg} \text { diet })\end{array}$ & $26.22 \pm 0.10^{\mathrm{a}}$ & $80.44 \pm 0.33^{b}$ & $0.93 \pm 0.01^{b}$ & $10.74 \pm 0.01^{\mathrm{b}}$ & $8.65 \pm 0.02^{b}$ & $3.34 \pm 0.02^{\mathrm{a}}$ \\
\hline 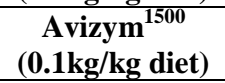 & $23.93 \pm 0.07^{b}$ & $82.65 \pm 0.53^{\mathrm{a}}$ & $0.95 \pm 0.03^{\mathrm{a}}$ & $11.39 \pm 0.02^{\mathrm{a}}$ & $9.22 \pm 0.01^{\mathrm{a}}$ & $2.86 \pm 0.01^{b}$ \\
\hline \multicolumn{7}{|c|}{ Interaction } \\
\hline $2900 \times 0.0$ & $24.45 \pm 0.09^{b}$ & $82.75 \pm 1.34^{\mathrm{a}}$ & $0.95 \pm 0.01^{\mathrm{a}}$ & $11.32 \pm 0.02^{\mathrm{a}}$ & $9.32 \pm 0.02^{\mathrm{a}}$ & $2.88 \pm 0.01^{\mathrm{b}}$ \\
\hline $2900 \times 0.1$ & $23.47 \pm 0.05^{b}$ & $83.01 \pm 1.42^{\mathrm{a}}$ & $0.95 \pm 0.02^{\mathrm{a}}$ & $11.43 \pm 0.01^{\mathrm{a}}$ & $9.30 \pm 0.01^{\mathrm{a}}$ & $2.78 \pm 0.02^{b}$ \\
\hline $2750 \times 0.0$ & $27.98 \pm 0.11^{\mathrm{a}}$ & $78.13 \pm 1.21^{b}$ & $0.90 \pm 0.01^{b}$ & $10.16 \pm 0.02^{b}$ & $7.97 \pm 0.02^{b}$ & $3.80 \pm 0.01^{\mathrm{a}}$ \\
\hline $2750 \times 0.1$ & $24.38 \pm 0.08^{\mathrm{b}}$ & $82.29 \pm 1.24^{\mathrm{a}}$ & $0.94 \pm 0.03^{\mathrm{a}}$ & $11.35 \pm 0.01^{\mathrm{a}}$ & $9.13 \pm 0.01^{\mathrm{a}}$ & $2.93 \pm 0.02^{b}$ \\
\hline
\end{tabular}

Means in the same column within the same effect having different letters are significantly different at $\mathrm{P} \leq 0.05$.
$\mathrm{FI}=$ Feed intake
EW = Egg weight
$\mathrm{EP}=$ Egg production
$\mathrm{EM}=$ Egg mass
$\mathrm{EN}=$ Egg number
$\mathrm{FCR}=$ Feed conversion ratio

\section{REFERENCES}

A. O. A. C. (1990). Association of Official Analytical Chemists. Official Methods of analysis $15^{\text {th }}$ Ed., published by Assoc. Office. Anal. Chem., Washington, D.C., USA.

Abbott, W. W.; J. R. Couch and R. L. Atkinson (1969). The incidence of footpad dermatitis in young turkeys fed high levels of soybean meal. Poult. Sci., 48: 2186-2188.

Abdel-Mageed M.A.A; E.M. EL-Kamash and Nadia, M.A. EL-Bahy (2013). Effect of multicarbohydrase enzymes on performance of Japanese quail fed optimal and sub-optimal energy levels. Fayoum J.Agric. Res. \& Dev., Vol 27, No.1, January.

Angel, C. R.; J. L. Sell and D. R. Zimmerman (1988). Autolysis of $\alpha$ galatactosides of defatted soy flakes: influence on nutritive value for chickens. J. Agric. Food Chem., 36: 542-546.

Brenes, A.; M. Smith; W. Guenter and R. R. Marquardt (1993). Effect of enzyme supplementation on the performance and digestive tract size of broiler chickens fed wheat- and barley-based diets. Poult. Sci., 72: 1731-1739.

Coon, C. N.; K. L. Leske; O. Akavanichan and T. K. Cheng (1990). Effect of oligosaccharide-free soybean meal on true metabolizable energy and fiber digestion in adult roosters. Poult. Sci., 69: 787-793.

Cowan, W. D; A. Korsbak; T. Hastrup and P. B. Rasmussen (1996). Influence of added microbial enzymes on energy and protein availability of selected feed ingredients. Anim. Feed Sci. Technol., 60: 311-319.

Duncan, D. B. (1955). Multiple range and multiple F- test. Biometrics, 11: 1-42.

Fayoum J. Agric. Res. \& Dev., Vol. 30, No.1, January, 2016 
Feed Composition Tables for Animal and Poultry Feedstuffs Used in Egypt (2001). Technical Bulletion No. 1, Central lab for Feed and Food; Ministry of Agriculture, Egypt.

Garcı'a, J.; R. Carabañ o; L. Pe'rez-Alba and J. C. de Blas (2000). Effect of fiber source on cecal fermentation and nitrogen recycled through cecotrophy in rabbits. J. Anim. Sci., 78: 638-646.

Gracia M. I.; M. J. Aranıbar; R. Lazaro; P. Medel and G. G. Mateos (2003). Alpha-amylase supplementation of broiler diets based on corn. Poult. Sci., 82: 436-442.

Hill, F. W. and R. Renne (1960). The metabolizable energy of soybean oil meals, soybean millfeeds and soybean hulls for the growing chick. Poult. Sci., 39: 579-583.

Hill, F. W.; D. L. Anderson; R. Renner and L. B. Carew Jr. (1960). Studies on the metabolizable energy of grains and grain products for chickens. Poult. Sci., 39: 573-579.

Honig, D. H. and J. J. Rakis (1979). Determination of the total pepsin-pancreatin indigestible content (dietary fiber) of soybean products, wheat bran and corn bran. J. Agric. Food Chem., 27: 1262-1266.

Iji, P. A. and D. R. Tivey (1998). Natural and synthetic oligosaccharides in broiler chicken diets. World's Poult. Sci. J., 54: 129-143.

Irish, G. G.; G. W. Barbour and H. L. Classen (1995). Removal of the $\alpha$ galactosides of sucrose from soybean meal using either ethanol extraction or exogenous $\alpha$-galactosidase and broiler performance. Poult. Sci., 74: 1484-1494.

Jackson, M. E.; K. Geronian; A. Knox; J. McNab and E. McCartney (2004). A dose response study with the enzyme $\beta$-mannanase in broilers provided with corn-soybean meal based diets in the absence of antibiotic growth promoters. Poult. Sci., 83: 1992-1996.

Jensen, L. S.; R. Martinson and G. Schumaie (1970). A foot pad dermatitis in turkey poults associated with soybean meal. Poult. Sci., 49: 76-82.

Kennedy, I. R.; O. D. Mwandemele and K. S. McWhirter (1985). Estimation of sucrose, raffinose and stachyose in soybean seeds. Food Chem., 17: 85-92.

Kidd, M. T.; G. W. Morgan, Jr.; C. J. Price; P. A. Welch and E. A. Fontana (2001). Enzyme supplementation to corn and soybean meal diets for broilers. J. Appl. Poult. Res., 10: 65-70.

Knudsen, K. E. (1997). Carbohydrate and lignin contents of plant materials used in animal feeding. Animal Feed Science and Technology, 67: 319-338.

Knudsen, K. E. (2001). The nutritional significance of dietary fiber analysis. Animal Feed Science and Technology, 90: 3-20.

Kocher, A.; M. Choct; G. Ross; J. Broz and T. K. Chung (2003). Effect of enzyme combinations on apparent metabolizable energy of corn-soybean meal based diets in broilers. J. Appl. Poult. Res., 12: 275-283.

Lamptey, A.; T. F. Brihkhaus; J. A. Greaves; E. A. Fontana and G. M. Smith (2001). Method for increasing breast meat yields in poultry. US. Pat. No. $6,174,558$.

Fayoum J. Agric. Res. \& Dev., Vol. 30, No.1, January, 2016 
EFFECT OF USING "AVIZYM 1500 " ENZYME.

Leske, K. L. and C. N. Coon (1999). Hydrogen gas production of broiler chicks in response to soybean meal and $\alpha$-galactoside free, ethanol-extracted soybean meal. Poult. Sci., 78: 1313-1316.

Leske, K. L., C. J. Jevne and C. N. Coon (1993). Effect of oligosaccharide additions on nitrogen-corrected true metabolizable energy of soy protein concentrate. Poult. Sci., 72: 664-668.

Marsman, G. J. P.; H. Gruppen; A. F. B. van der Poel; A. F. Kwakkel; M. W. A. Verstegen and A. G. J. Vogagen (1997). The effect of thermal processing and enzyme treatments of soybean meal on growth performance, ileal nutrient digestibilities, and chyme characteristics in broiler chicks. Poult. Sci., 76: 864-872.

National Research Council, N. R. C. (1982). United States-Canadian Tables of Feed Composition. 3 rev. National Academy Press, rd Washington, DC.

North, M. O. (1981). Commercial Chicken Production Manual, $2^{\text {nd }}$ Edition. AVI Publishing Company INC, USA.

Obi, I. U. (1990). Statistical methods of detecting differences between treatment means. $2^{\text {nd }}$ edn. Snaap Press, Enugu, Nigeria.

Pan, B. H.; D. F. Li; X. S. Piao; L. Y. Zhang and L. Guo (2002). Effect of dietary supplementation with $\alpha$-galactosidase preparation and stachyose on growth performance, nutrient digestibility and intestinal bacterial populations of piglets. Arch. Anim. Nutr., 56: 327-337.

Park, J. S.; I. H. Kim; J. D. Hancock; R. H. Hines; C. Cobb; H. Cao; J. W. Hong and O.S. Kwon (2003). Effects of amylase and cellulase supplementation in sorghum-based diets for finishing pigs. Asian-Aust. J. Anim. Sci., 16:70-76.

Pluske, J. R. and M. D. Lindemann (1998). Maximizing the response in pigs and poultry diets containing vegetable proteins by enzyme supplementation. In: Biotechnology in the Feed Industry. Proc. of Alltech's $14^{\text {th }}$ Annu. Symp. Lyons, (Ed. T.P. Lyons and K.A. Jacques). Nottingham Univ. Press, Nottingham, UK., pp. 375-379.

Potter, L. M. and E. D. Matterson (1960). Metabolizable energy of ingredients for chickens. Rep. 9. Conn. Agr. Exp. Sta. Program, New Haven CT

Selle, P. H.; V. Ravindran; G. Ravindran; P. H. Pittolo and W. L. Bryden (2003). Influence of phytase and xylanase supplementation on growth performance and nutrient utilisation of broilers offered wheat-based diets. Asian-Aust. J. Anim. Sci., 16: 394-402.

Shim, Y. H.; B. J. Chae and J. H. Lee (2004). Effects of phytase and enzyme complex supplementation to diets with different nutrient levels on growth performance and ileal nutrient digestibility of weaned pigs. Asian-Aust. J. Anim. Sci., 17:523-532.

Sibbald, I. R. and S. J. Slinger (1962). The metabolizable energy of materials fed to growing chicks. Poult. Sci., 41: 1612-1613.

SPSS (1993). SPSS Statistical software Package for the social sciences. 2 nd ed. HA33-N48. McGrow-Hill, Inc., USA.

Steel, R. G. D. and J. H. Torrie (1980). Principles and procedures of statistics: A Biometrical $2^{\text {nd }}$ ed. McGraw-Hill Book Co., Inc., New York, USA

Fayoum J. Agric. Res. \& Dev., Vol. 30, No.1, January, 2016 
Sudo, S. Z., and G. E. Duke (1980). Kinetics of absorption of volatile fatty acids from the ceca of domestic turkeys. Comp. Biochem. Physiol., 67A: 231237.

Sugimoto, H. and J. P. Van Buren (1970). Removal of oligosaccharides from soy milk by an enzyme from Aspergillus saitoi. J. Food Sci., 35: 655-660.

Tahir, M.; F. Saleh; A. Ohtsuka and K. Hayashi (2005). Synergistic effect of cellulose and hemicellulase on nutrient utilization and performance in broilers fed a corn-soybean meal diet. J. Anim. Sci., 76: 559-565.

Van der Klis, J. D.; A. Van Voorst and C. Van Kruyningen (1993). Effect of a soluble polysaccharide (carboxymethyl cellulose) on the physico-chemical conditions in the gastrointestinal tract of broilers. Br. Poult. Sci., 34: $971-$ 983.

Wagner, J., R. Becker; M. R. Gumbmann and A. C. Olson. (1976). Hydrogen production in the rat following ingestion of raffinose, stachyose, and oligosaccharide-free bean residue. J. Nutr., 106: 466-470.

Waldroup, P.; C. Keen; F. Yan and K. Zhang (2006). The effect of levels of alphagalactosidase enzyme on performance of broilers fed diets based on corn and soybean meal. J. App. Poult. Res., 15(1): 48-57.

Zhang, L. Y.; D. F. Li; S. Y. Qiao; J. T. Wang; L. Bai; Z. Y. Wang and I. K. Han (2001). The effect of soybean galactooligosaccharides on nutrient and energy digestibility and digesta transit time in weanling piglets. AsianAust. J. Anim. Sci., 14(11): 1598-1604.

$$
\begin{aligned}
& \text { تأثير استخدام انزيم الافيزايم .'10 على أداء كتاكيت السمان اليابانى المغذى على مستويات مثلى وتحت }
\end{aligned}
$$

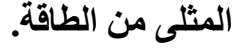

$$
\begin{aligned}
& \text { محمد أحمد على عبد المجيد - عزت موسى عبد التواب القماش } \\
& \text { معهد بحوث الإنتاج الحيو اني ـ الدقي - جيزة - مصر. }
\end{aligned}
$$

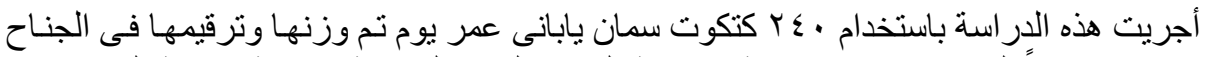

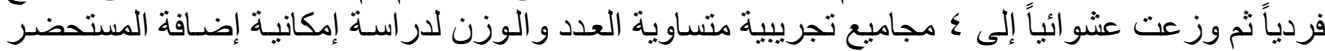

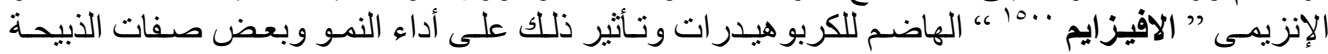

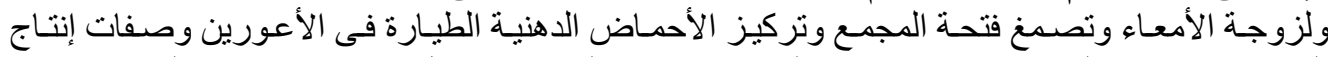

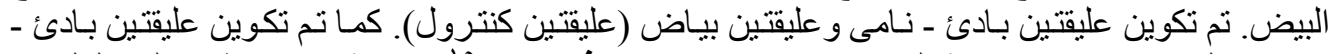

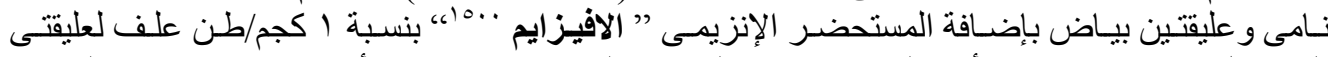

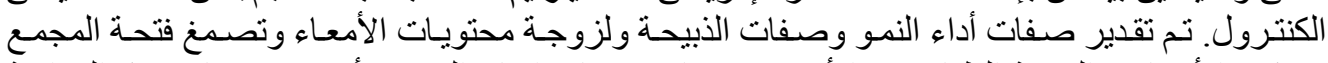

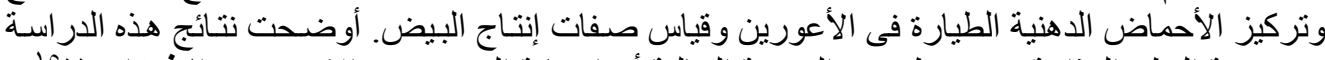

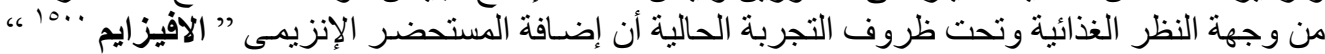

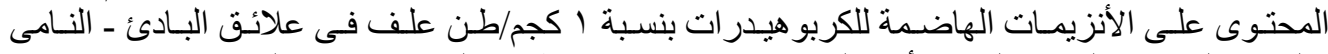

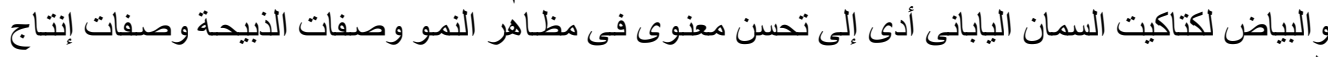

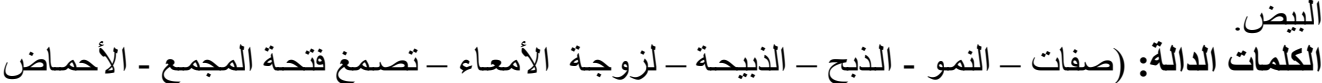
الدهنية الطيارة - إنتاج البيض - سمان يابانى).

Fayoum J. Agric. Res. \& Dev., Vol. 30, No.1, January, 2016 